\title{
JÚDICE, Nuno. Fórmulas de uma luz inexplicável. 2. ed. Lisboa: Publicações Dom Quixote, 2012. $109 \mathrm{p}$.
}

Wagner Moreira

Centro Federal de Educação Tecnológica de Minas Gerais

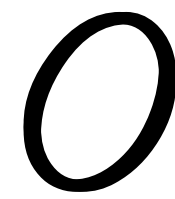

s oitenta e cinco poemas que compõem o último livro de Nuno Júdice cumprem um percurso poético que confirma as fundamentais linhas de força da obra do poeta, quais sejam, a preocupação metalinguística, o diálogo com as expressões artísticas, o exercício da memória, a vivência do afeto amoroso e o estranhamento diante do fenômeno da morte.

O título Fórmulas de uma luz inexplicável nos apresenta a variedade no tratamento temático por meio do plural de seu primeiro vocábulo, além de nos remeter para a ideia de uma programação poética elaborada racionalmente. Nesse sentido, o termo "luz" corrobora a face de lógica aparente que tende para uma expressão objetiva do corpo poético. Contudo, a iluminação que determina aquele termo abre a sua significação para o indeterminado, o imensurável, o inominado, quando é modificada pelo caráter daquilo que traz em si um grau acentuado de mistério, porque impossível de se dizer a maneira pela qual o iluminado se constitui, ou melhor, se institui. Pode-se afirmar, com base no título, que este livro se apresenta como o exercício criativo antagônico, por excelência. 
A concatenação dos poemas apresenta uma organicidade que faz pensar em uma perspectiva predominantemente clássica e, simultaneamente, moderna. A primeira se pode ver pelos títulos dos textos que iniciam o livro: ele se abre com o poema "Projecto", seguido de "Invocação", "Te deum" e "Cena bíblica" - quase replicando, pela insinuação dos títulos, as categorias do poema épico clássico, como a introdução, subdividida em proposição, invocação e oferecimento, seguido dos poemas que configurariam a narração, constituída por oitenta poemas e finalizado pelo poema homônimo à última parte do texto épico "Epílogo". Ressalte-se o valor poético moderno tanto da forma quanto do conteúdo de diversos poemas, o que faz pensar em um fazer criativo que se apresenta como uma inserção na tradição canônica consciente.

Destaque-se na fração que corresponde à exposição escrita dos acontecimentos o poema "Situação":

Tinha-a visto na varanda, fumando um cigarro, olhando para sítio nenhum, e tão imóvel que nem se dava pelo fumo que envolvia o seu rosto e a transformava em aparição que, com o cair da tarde, se materializava em sombra. Ainda tentei adivinhar em que direção seguiam os seus olhos, mas de onde eu estava só via o rosto num esboço de perfil, como se o seu corpo estivesse inacabado sobre um suporte de nuvem. Depois, a varanda ficou vazia, quando acabou o cigarro, e foi como se nunca tivesse existido, com a noite a cobrir a fachada. ${ }^{1}$

${ }^{1}$ JÚDICE, 2012, p. 44. 
Ele funciona como uma amostra do viés do olhar moderno sobre a disposição e ordem dos elementos tradicionais, ao enfatizar o papel do sujeito como um observador do outro. Neste caso, o ser percebido é feminino e, como o próprio olhar deste que se perde no vazio, se esvai aos poucos, deixando ver o aumento de sua obscuridade até chegar à completa ausência. Esse processo de exaustão do ser parece provocar o esvaziamento do próprio ambiente ao qual pertence. Dessa maneira, a tarde, convertida em noite, dá a presença do obscurecimento e da anulação do ambiente e do eu. Por outra via, o poeta apresenta a falta como uma experiência que se define em relação ao outro e ao meio em que está.

Outro procedimento que vai em direção a esse espaço poético é a memória. Vários são os poemas que se fazem por essa conduta, como por exemplo, "Elegia", no qual o ser amado se apresenta como construção memorialística de uma vivência que se faz imagem poética, na tentativa de recuperar o evento amoroso perdido: "[...] Só tu, que saíste da minha memória para / esse bailado nocturno, me pedes: "Lembra-te de mim; / não percas a minha imagem; e sente, nas tuas mãos, / o corpo que perdeste, para fazeres o caminho de volta". Assim, o diálogo com a tradição deixa de lado o efeito coletivo dos grandes feitos de uma nação para exaltar o sujeito e suas perdas, com o seu novo modo de recuperar o que lhe cabe apenas como história.

Retomando a face de exercício metapoético, verifica-se, por exemplo, o trabalho que faz coincidir forma e mensagem no poema "Carta de Mallarmé a Méry Laurent", no qual os versos "[...] mas dobras-te ligeiramente para um fim / de verso que o vento arrastou até o limite / da página [...]" trazem para a experiência da leitura o valor visual mesclado ao que se diz, reforçando o processo significativo do texto. Ou ainda, ao se observar "O equívoco das ruas", deve-se destacar a procura da poesia como algo que se faz a partir da vivência cotidiana, como 
se pode ver nos versos "Foi então que terei começado a procurar a / diferença entre o que é e não é poético". E no mesmo poema, verifica-se a percepção do poético como não sendo apenas o exercício com a linguagem, com a língua, o que aponta para uma espécie de jogo entre a aparência e a essência, a realidade e o sentido construído: "[...] De facto, ia juntando as frases sob / a forma poética, estrofe após estrofe; mas / a questão que eu punha era se isso bastaria para / eu ter um poema". Para suplementar essa noção de poesia, deve-se ressaltar que ela é uma transformação insone, o que reforça o seu lado de linguagem onírica, apesar da aparência clara.

Além da literatura, o cinema, o desenho, a pintura e a fotografia estão entre os temas que atravessam o livro. Isto explica o caráter imagético da poesia de Nuno Júdice em seu afã de compor uma imagem que seja poética e não mera reprodução subjetiva ou realista. Verifica-se nesse ponto o exercício do imaginário daquele que apresenta o outro na condição de vacância, aquele que se perde através de um olhar disperso. Vejam-se os versos de "Fotografia de Camille Claudel no hospício": "Os olhos perdidos num pedaço de parede, procura / um outro ponto em que os fixar: e volta-os / para dentro de si [...]". Ou "[...] bastar-lhe-ia um pouco de / sonho para encontrar esse vazio a que aspira, / ou apenas o último ângulo entre infinito / e eternidade". Essa abertura para um estado que ultrapassa o horizonte possível de experimentação aponta para uma matéria do poético muito cara a este livro, a ausência: "[...] como se procurasse moldar um / corpo antigo com o barro seco da ausência". O trato com a tradição pode ser entendido como o material utilizado por Claudel ou, por um processo de identificação com o poeta, dado pelo exercício da admiração e da anunciação da loucura do ser que o deslumbra, pela poesia de Júdice, sendo uma recorrência de escrita. 
Para além desse tipo de amor que se constitui através da distância daquele que se admira, há também o afeto que parece derivar de uma vivência pessoal e devaneadora. O poema "Modelo ao ar livre" expõe esse sentimento terno de adesão por uma pessoa inominada. Ele é uma descrição não objetiva, apesar de clara, do corpo feminino. Esse traçado está constituído essencialmente pela linguagem verbal, e insinua uma troca com a pintura e com a natureza. Então, a cena maviosa surge com um caráter híbrido, pois o corpo amado é todo o processo que se apresenta na realidade da observação, na tradução para os grafismos de uma página-tela como uma expressão que está para além do que é natural. A face de liberdade aqui é menos o nu insinuado e mais o desnudamento de se embevecer pelo belo em si - paixão maior do poeta:

Seguindo o sulco negro das consoantes dos teus cabelos, desenho lentamente os traços do teu rosto. O meu objetivo é recortá-lo do papel e ver-te à transparência da página, limpando de vogais as tuas faces. Ponho-te neste retrato de olhos fechados, e colho dos teus lábios as pétalas que caíram com as sílabas do amor, para as voltar a pousar nas mãos que me estendes. Depois, vou buscar a luz que me falta ao fundo da tarde, e derramo-a pelo teu corpo, vendo soltarem-se da tua pele as gotas primaveris de um céu límpido como a imagem que aqui vejo florescer. ${ }^{2}$

Em "Às vezes", o sentimento de morte se anuncia já no primeiro verso: "Às vezes sentimos que o tempo chegou ao fim [...]". E com ele a sensação de estranhamento diante do existir,

${ }^{1}$ JÚDICE, 2012, p. 51. 
o que torna o viver profundamente afetado pelo peso do que se transforma em algo sem a intimidade necessária para que se possa reconhecer todo o percurso experimentado. Mais ainda, vê-se o desejo de se livrar desse "amargo sabor" ofertado pela morte e, dessa forma, lançar-se a um espaço de liberdade único, onde coragem e amor devolvem a vida daquele que sabe lidar com o evento derradeiro.

É essa a configuração do livro Fórmulas de uma luzinexplicável, de Nuno Júdice. Um complexo trabalho criativo com a palavra que se revela com a sutileza da expressão poética contemporânea ao oferecer ao leitor um universo singular a partir de corriqueiras cenas. Forma concisa e rigorosa que expõe o fato artístico como a linguagem iluminada do ser, a poesia. 